\title{
Problems and Countermeasures in Cross Cultural Teaching of College English
}

\section{Luo Yafeng}

Weinan Normal University, School of Foreign Studies, Weinan, Shaanxi, 714000

Keywords: College English, Cross-Cultural Teaching, Problems, Countermeasures

\begin{abstract}
In recent years, with the rapid development of economic level and science and technology, all fields of society are constantly reforming, and the field of education is no exception. As a universal language, English is widely used in international communication. Especially after China's entry to WTO, there is more and more international cooperation. The demand for English talents is rising linearly. This paper analyzes the problems existing in intercultural teaching of College English, finds out the causes of problems in teaching, and puts forward corresponding countermeasures, so as to provide reference for solving the problem of intercultural teaching in College English.
\end{abstract}

\section{Introduction}

With the rapid development of world economic integration and cultural diversity, the curriculum in universities is also constantly reforming. The international cooperation among various industries is becoming more and more closely related, and the demand for English talents is also increasing. As a universal language of communication in the world, English plays an important role in international cooperation, facilitates foreign economic exchanges and promotes the prosperity and development of social economy [1-2]. The quality of cross culture teaching in College English is related to the level of students' English professional skills, so all walks of life have put forward new requirements. Although the cross culture teaching of College English in China has been constantly reform and perfected in recent years, some achievements have been achieved, but there are still many problems.

\section{An Overview of Cross Culture Teaching in College English}

Language is the main way to realize the transmission of information between people. It is also the carrier of culture. Culture can be transmitted in the form of language. As an international language, English can effectively improve the efficiency of international communication and promote the prosperity and development of the world economy. Therefore, it is necessary to improve the teaching level of College English so as to improve the English professional level of college students [3]. With the deepening of the reform of education, English teaching has introduced the research of western culture in the introduction of basic knowledge. Intercultural teaching in College English is to cultivate students' intercultural communicative competence and to enhance their ability to use English on the basis of fully understanding western culture and local conditions.

The cross culture teaching of College English can effectively promote the students to have a correct understanding of the culture and customs of different nationalities. The environment required by English classroom is quite different from that of college students. College students are also used to treat everything around their mother tongue. This will increase the difficulty of cross-cultural English classroom, and it is difficult for students to adapt to it. Therefore, intercultural teaching is introduced into the teaching process, introducing western cultural phenomena and customs to guide students to pay attention to different social life, cultural background and so on [4]. Changing students' traditional ideas, adopting a compatible and open mindset to accept foreign cultures, effectively improving students' English learning ability, so as to improve the quality of English teaching. 


\section{Problems in Cross Cultural Teaching of College English}

The traditional English teaching methods in our country are generally centered on the teaching of language knowledge, such as the analysis of words and the explanation of grammar, etc. The teaching thought of light culture and language makes the teaching of College English stay in the language itself and ignore the use value of language as a tool [5]. With the development of economic globalization and cultural diversity, the traditional teaching concept is no longer suitable for the development of the current society. The concept of intercultural teaching has become the focus of the reform of College English teaching. However, there are still some problems in the process of intercultural teaching.

\subsection{The lack of theoretical support for cross culture teaching in College English}

The English teaching in our country lacks a perfect theoretical system and lacks clear planning and guidance. In the process of reform of College English, without considering China's national conditions, the introduction of foreign teaching ideas directly leads to the fact that the teaching idea is not completely consistent with the actual situation of China, and cross-cultural teaching can't give full play to its value. In addition, the leaders and administrators of the relevant departments do not attach importance to the cross-cultural teaching of College English. There is also lack of scientific theoretical guidance for the design of intercultural curriculum and compilation of textbooks. Although the Ministry of Education issued several teaching documents and outlines, it did not mention the importance of culture teaching, nor did it systematically and systematically discuss culture teaching [6-7]. This makes the cross-cultural teaching of College English lack of scientific and perfect theoretical support. It can only rely on the personal interest of university teachers, and there is a big gap between the cross culture teaching and the real cross culture teaching.

\subsection{The problems of teachers' own existence}

Teacher is a key link in College English teaching. Teachers' knowledge structure and attitude towards culture are related to the success or failure of cross-cultural teaching. However, the cultural quality of English teachers in Colleges and universities in our country is lack, and the reserve of cultural knowledge is less. The number of English learners in China is large and the outstanding English teachers are short, which makes the overall quality of teaching not high. According to the survey results, our English teachers don't know much about language and culture learning in other countries, or even have some wrong understandings and prejudices, so it is difficult to form a complete system [8]. The conservative education concept is greatly influenced by the traditional teaching mode, and there is no comprehensive understanding and understanding of the cross culture teaching. Though they also realized the importance of intercultural teaching to English teaching, they abandoned it in teaching practice, and always followed the traditional teaching mode to carry out College English teaching.

\subsection{College English textbooks lack cross cultural content}

The existing education system in China is still dominated by textbooks. However, English textbooks in China rarely involve foreign cultural contents, nor do they have corresponding cultural universal laws. At present, there is a lack of systematic and complete teaching contents in Chinese College English textbooks, and there are no related auxiliary cultural teaching materials, including dictionaries, etc., and there are no cultural interpretations. College English textbooks, not even Chinese traditional culture, has a serious impact on the establishment of students' cultural awareness of equality and discrimination; China's English teaching in common is that of science and technology and the lack of spiritual material, involving values, national psychology and thinking patterns are less. These will hinder the cultivation of students' cross-cultural communication ability.

\subsection{The problem of the student's own existence}

In the cross culture teaching of College English, teachers are the dominant part of teaching. Students are the main body of learning, and teachers guide students to learn. However, students' 
learning attitude is the ultimate factor that influences the success or failure of learning. After investigation and research, it is found that college students lack corresponding understanding of culture. They wrongly believe that people's life habits and religious customs are not part of culture. In the west, culture comes from life, religion is a kind of belief, and it is an important part of culture. Secondly, the concept of their perceptions of cultural learning fuzzy, lack of awareness, lack of unified understanding of the culture of college students learning interest; then, the impact of examination oriented education, English learning utilitarian, foreign culture as the content of the examination, so students will not pay attention to cultural learning [9].

\section{An Analysis of the Causes of Cross Culture Teaching in College English}

Through investigation and analysis, it is found that Chinese university teachers and students do not pay much attention to cross-cultural teaching. There are many problems in teaching mode, teaching material content and assessment mode. Teachers and students do not care about foreign culture. There are many problems in cross-cultural teaching, which seriously affect the quality of English teaching in China [10]. Therefore, we need to make a careful analysis of the existing problems, find out the causes of the problems, and fundamentally solve the problems existing in the cross cultural teaching of College English, and promote the effective development of English teaching.

\subsection{Biased teaching ideas, lack of cultural teaching and unbalance of content selection}

The cross culture teaching in China started late and lacked systematic and scientific nature. The main reason for this problem is China's contempt for cross cultural English teaching policy orientation. There are no cross-cultural education contents in teaching syllabus, teaching materials, teaching models and assessment. In the course of actual teaching, the teachers only rely on their own interests to tell the students some cultural background knowledge. This teaching model will not only improve the students' cross-cultural communication ability, but also increase the students' prejudice to the foreign culture [11]. Teachers themselves lack cultural training and cultural experience, lack of cultural awareness and lack of cultural knowledge. Secondly, the lack of cultural teaching, the focus of English teaching in China has always been phonetics, grammar and vocabulary and other studies and explanations. English examination and evaluation are also centered on this. Therefore, college teachers also regard English language as their research and teaching goal, and form a complete teaching system. In the process of examination and learning, we should pay attention to the correctness and fluency of language forms, and ignore the use and effectiveness of language. The cultural connotation of English language is not fully utilized, and the communicative competence of students cannot be effectively promoted. The final content of the selection imbalance, resulting in the loss of Chinese traditional culture and education. In the process of College English teaching, we should pay attention to cultural learning in English, emphasize the transfer of mother tongue in English learning, but fail to integrate Chinese excellent traditional culture into English learning, which results in the phenomenon of "Chinese Culture Aphasia".

\subsection{The teaching method is lagging behind and the teaching goal is blurred}

The teaching method is obsolete, the teaching mode is single, and the independent initiative of the students can not be fully mobilized, and the teachers and students lack the corresponding communication and cooperation. Teachers can not use various teaching methods flexibly to achieve cross-cultural teaching. Although in recent years, College English teachers have a new awareness of the new teaching methods, and have also carried out a preliminary attempt, but the application is very limited. In addition, teachers can not transfer effective learning strategies and methods to students in the course of teaching, which leads to unreasonable teaching strategies. The teacher mainly teaches the learning method to the students, and trains the students to master the learning strategies, thus effectively improving the learning efficiency and teaching quality. However, according to the survey results, there is a small number of students who are able to skillfully learn learning strategies and lack of teaching strategies. 


\section{A Study of Cross Culture Teaching Strategies for College English}

The cross culture teaching mode of College English is to integrate language teaching and culture teaching, improve teachers' professional quality and cultural quality, and comprehensively reform cross-cultural teaching objectives, teaching contents and teaching activities [12]. Therefore, it is necessary to adopt appropriate teaching strategies to promote the scientific integrity of the intercultural teaching system.

\subsection{The cognitive system of intercultural communication ability training}

The cognitive system of intercultural communicative competence involves many aspects, such as cultural knowledge, and its own values. Therefore, in order to cultivate a complete cognitive system of intercultural communication ability, we should first set up the correct teaching idea, update the concept in time, and improve the understanding. The national educational institutions should have a full understanding of them. The experts and leaders of the administrative departments should actively learn from the successful experience of foreign countries, and clarify the direction of cross-cultural teaching according to our national conditions. With a brand-new teaching idea and teaching mode, we can promote cross-cultural teaching in College English, deepen teachers' cognition of intercultural teaching, reform examination system, improve the importance of teachers and students, and better invest in intercultural teaching. Secondly, we must clarify the teaching objectives. The Ministry of Education promulgated the "College English curriculum requirements" in 2007, and clarified the teaching objectives of College English curriculum, emphasizing the training of students' Comprehensive English application ability and improving the standard of College English teaching.

\subsection{Establishing the principles of cross culture teaching in College English}

The essence of intercultural foreign language teaching is to realize the social communicative nature of English, and to cultivate the students' communicative competence in the identification and understanding of cultural knowledge. In the course of teaching, it is necessary to follow the cultural rules and social communicative thinking. Intercultural teaching in College English should be centered on students. In the process of teaching, besides the imparting of basic knowledge, students' autonomous learning ability should also be cultivated. Take the students as the main body of the class, guide the students to participate in the cultural experience together, understand the relationship between language and culture, and construct the cultural value orientation. In the course of teaching, we should pay attention to the diversified cooperation between the individual and the group, and arrange the content of cultural learning reasonably. According to the direction of students' cognition, from shallow to deep, from image thinking to logical thinking, we should arrange cultural knowledge system and relevance, so as to help students to grasp cultural knowledge comprehensively and effectively.

\section{Conclusion}

The cross culture teaching of College English conforms to the trend of curriculum reform in Colleges and universities, promotes the exchange of internationalization, and improves the prosperity and development of the economy. In the background of the reform, this paper analyzes the problems of cross culture teaching in College English, and finds out the main reasons for the problems. The paper puts forward some countermeasures and suggestions to improve students' ability to apply English learning and teaching efficiency.

\section{References}

[1] Zhu X. Current problems and countermeasures in college English translation teaching[J]. Journal of Anshan Normal University, 2015.

[2] Liu C Y. Problems and Countermeasures of Students' Learning Motivation Degradation in 
College English Teaching[J]. Theory \& Practice of Education, 2016.

[3] Yu Y. Problems and countermeasures of college English teaching transformation in the era of Internet $+[\mathrm{C}] / /$ International Conference on Education, Sports, Arts and Management Engineering. 2017.

[4] Zhu M. On the Problems and Countermeasures of English Teaching in Higher Vocational Colleges[J]. Science Education Article Collects, 2017.

[5] Lin J, Duan Z. A Study on Some Problems and Countermeasures in College English Teaching[C]// International Conference on Education, Management and Computing Technology. 2017.

[6] Yang J H. Applied undergraduate college English writing teaching problems and countermeasures[J]. Journal of Hebei University of Engineering, 2016.

[7] Zhang H L. A Study on the Deep Problems and Rational Countermeasures of College English Grade Teaching[J]. Journal of Hubei Correspondence University, 2015.

[8] Wang Y Y. On the Problems of College English Teaching and Countermeasures in Large Classes[J]. Journal of Shangluo University, 2015.

[9] Xiao L. Problems and Countermeasures of the College English Effective Teaching[C]// International Conference on Education, Management, Computer and Society. 2017.

[10] Yang S. Misunderstandings and countermeasures in college English listening teaching[J]. Journal of Jiamusi Vocational Institute, 2017.

[11] Zhang S, Deng F, Yao L. Problems and Countermeasures of Anatomical English Teaching of International Students of Applied Undergraduate Medical College[J]. Continuing Medical Education, 2016.

[12] Li J, Wang Y. On Current Situation, Defects and Countermeasures of College English Classroom Teaching Mode[C]// International Conference on Management Science, Education Technology, Arts, Social Science and Economics. 2016. 